\title{
Effect of Pegagan and Beluntas Combination on Diestrus Length and Proliferation of Vaginal Epithelium on Rattus norvegicus
}

\author{
$1^{\text {st }}$ Bayyinatul Muchtaromah ${ }^{1}, 2^{\text {nd }}$ Amanatul Mubdah ${ }^{1}, 3^{\text {rd }}$ Bayu Agung Prahardika ${ }^{1}$ \\ \{bayyinatul_uin@yahoo.co.id ${ }^{1}$ \} \\ UIN Maulana Malik Ibrahim, Faculty of Science and Technology, Malang, Indonesia ${ }^{1}$
}

\begin{abstract}
A variety of reproductive health problems often appear to both men and women, so it takes a natural remedy to reduce the usual side effects on the use of chemical drugs. The people of Indonesia have widely known Pegagan (Centella asiatica) and Beluntas (Pluchea indica) as a plant that has benefits as a medicine. The effect of leaf extract of $\mathrm{C}$. Asiatica and $\mathrm{P}$. indica on the female reproductive system can be known by the change of the estrous cycle, especially in diestrus phase and vagina proliferation. This study used 24 Wistar female rats, aged of 2 months, and weighed of 120-150 g. Combination of pegagan and beluntas extract utilizing a ratio of 1: 1 . The treatment consisted of control (C) dose of $0 \mathrm{mg} / \mathrm{kg} \mathrm{bw}$, the first treatment (T1) $25 \mathrm{mg} / \mathrm{kg}$ bw, the second (T2) $50 \mathrm{mg} / \mathrm{kg}$ bw, the third (T3) $75 \mathrm{mg} / \mathrm{kg}$ bw, the fourth (T4) $125 \mathrm{mg} / \mathrm{kg}$ bw and the fifth (T5) is $200 \mathrm{mg} / \mathrm{kg}$ bw. Data were analyzed using ANOVA $(\alpha 5 \%)$ if there were a significant difference then tested continued using DMRT ( $\alpha$ 5\%). The results showed that combination of leaf extract of pegagan and beluntas significantly influenced the proliferation of vaginal epithelium, indicated by the increase of maturation index and vaginal epithelial thickness, but did not affect to the length of diestrus. The highest vaginal maturation index and vaginal ephitelial thickness value obtained by a T4 dose of $75 \mathrm{mg} / \mathrm{kg}$ bw, thus this dose was the most optimal for use as a fertility supplement.
\end{abstract}

Keywords: Pegagan and beluntas leaf extract; diestrus; vaginal maturation index; vaginal epithelium thickness

\section{Introduction}

Microscopic evaluation of the types of cells in the vaginal smear has long been used to document the stages of the estrous cycle in rats and as an index of the functional status of the hypothalamic-pituitary-ovarian. Thus, the estrus cycle assessment has been used both as a primary measure in the determination of reproductive cycles and as additional tests in reproductive studies [1].

The reproductive system is one of the physiological processes that occur in living things to sustain offspring and survival. Several problems of the female reproductive system include menstrual cycle disorders (estrus), dysmenorrhea, vaginal discharge, bleeding during menstruation and other reproductive disorder can interfere with fertility [2]. Therefore, it takes drugs that can solve the problem. However, the use of chemical medicines so far is feared will 
have a negative impact on the reproductive system. Herbal medicine is believed to cause fewer side effects and beneficial to a human with many advantages.

Medicinal plants commonly used by Indonesian people include Pegagan (Centella asiatica) and Beluntas (Pluchea indica). Pegagan (C. Asiatica) is one of the favorite herbs among Malaysians and Indonesians, and it has been widely used as ulam or folk medicine in many countries. This plant contains high bioactive compounds such as madecassoside, madecassic acid, asiaticoside (glycoside) and asiatic acid (terpene acid) which are related to medicinal properties. C. asiatica leaves extract can be used for wound healing, acts as an alternative treatment for various diseases, and has fertility and antifertility properties [3][4]. Andria research reported that ethanol extract of pegagan at high dose 560,630 , and $700 \mathrm{mg} / \mathrm{kg}$ bw decreased on estrogen levels [5]. Muchtaromah revealed that combination of pegagan and beluntas dose of $25,50,75 \mathrm{mg} / \mathrm{kg}$ bw elevated total follicle, and ovulation number of ovarium but the dose of 125 and $200 \mathrm{mg} / \mathrm{kg}$ bw declined these parameters [6].

The active compounds were found in $P$. indica leaves such as lignans, terpenes, phenylpropanoids, benzoids, tannins, flavonoids, and hydroquinone phenols, which were reported to reduce the number of spermatogenic cells and testosterone [7]. The community uses Beluntas as an anti-inflammatory, antibacterial, pathologies vaginal discharge, menstrual disturbances, and hepatoprotector drug [8][9]. Fajriaty's study reported that the administration of $945 \mathrm{mg}$ and $9450 \mathrm{mg}$ of beluntas extracts prolonged the metestrus and diestrus phases and shortened the proestrus and estrus phases [10].

The combination of pegagan and beluntas is used traditionally by the people of West Sumatra as fertility herbs (to get a baby), with a dose of 1 handheld consumed two times a day [9]. The results of the combination can be both synergistic and antagonistic. The results were said to be synergistic if the combinations had a more significant effect than a single use, then called an antagonist if the combination results had a smaller impact than a single application. Based on the background, It was hoped that research of combination of pegagan and beluntas in several doses would produce beneficial effects for the fertility supplement, which could be determined by vaginal cytology and histology (diestrus length, vaginal maturation index and vaginal epithelial thickness)

\section{Methods}

\subsection{Experimental design}

This study used wistar strain female rats, two months old, weight 120-150 g. The sample size was about 24 rats divided into six treatment groups; each group consisted of 4 rats as replicates.

The treatment group was divided as follows: Control $(\mathrm{C})$ : rats treated with extract of pegagan dose of $0 \mathrm{mg} / \mathrm{kg}$ bw + beluntas $0 \mathrm{mg} / \mathrm{kg}$ bw; T1: pegagan $25 \mathrm{mg} / \mathrm{kg}$ bw + beluntas $25 \mathrm{mg} / \mathrm{kg}$ bw; T2: pegagan $50 \mathrm{mg} / \mathrm{kg}$ bw + beluntas $50 \mathrm{mg} / \mathrm{kg}$ bw; T3: pegagan $75 \mathrm{mg} / \mathrm{kg}$ bw + beluntas $75 \mathrm{mg} / \mathrm{kg}$ bw, T4: pegagan $125 \mathrm{mg} / \mathrm{kg}$ bw + beluntas $125 \mathrm{mg} / \mathrm{kg}$ bw; T5:pegagan $200 \mathrm{mg} / \mathrm{kg}$ bw + beluntas $200 \mathrm{mg} / \mathrm{kg}$ bw.

\subsection{Extraction}

The fresh leaves of pegagan and beluntas were obtained from Materia Medica, Batu Malang. The procedure for the extraction referred to the process previously described by [11] [12] on C. asiatica leaves. The extract was dissolved in $\mathrm{NaCMC} 0.05 \%$ and given orally 2.5 
$\mathrm{ml}$ daily for $15 \mathrm{~d}$. The extract was administered $3 \mathrm{~d}$ after the injection of prostaglandin hormone $0.01 \mathrm{ml} / \mathrm{head}$.

\subsection{Vaginal Smear Method}

To collect cells from the vaginal canal, approximately $0.2 \mathrm{ml}$ of saline was drawn into the pipette or dropper. The tip of the dropper was gently inserted into the vaginal orifice at a depth of approximately $5-10 \mathrm{~mm}$ and then the saline flushed into the vagina and back out 2 or 3 times. After the lavage, a small drop of the sample was then placed evenly on the slide in a thin layer (smear) and allowed to air dry. Giemsa staining was used for the identification of the different cell types of vaginal smears [1].

A light microscope observed the result of vaginal swab with 100x magnification. The length phase of diestrus was determined by comparison of nucleated epithelial cells, cornified epithelial cells, and leucocytes on the vaginal smears. Comparison of cell types in vaginal smears and diestrus phase in estrous cycles was referred to [13]. The estrous cycle examination was performed daily for $15 \mathrm{~d}$ of treatment. A surgery was performed after $15 \mathrm{~d}$ of treatment and confirmed in the diestrus phase. The rat was sacrificed by servical dislocation and dissected at the median region of the vagina for making histology preparation with hematoxilin eosin staining. The preparation was observed and photographed. Vaginal maturation index (VMI) was described the relative proportion of parabasal, intermediate and superficial cells in vaginal cytology (PB: I:S). VMI was obtained by the following formula $(\mathrm{PB} \times 0)+(\mathrm{I} \times 0.5)+(\mathrm{S} \times 1)[14]$. Cell maturation evaluation was calculated at least 100 cells under a light microscope with 400 magnification, through the ratio of parabasal, intermediate, and superficial cells in one field of vision repeated up to 8 fields of view in 1 preparation [15]. The thickness of the vaginal epithelium was calculated using the Image Raster application starting from the lumen edge. This was repeated up to 8 times the field of view on one preparation.

\subsection{Data Analysis}

Data of diestrus length, vaginal maturation index, and vaginal epithelial thickness were analyzed using one way anova test $(\alpha 5 \%)$. If the $\mathrm{F}$ count $>\mathrm{F}$ table then conducted a further test with Duncan Mean Range Test ( $\alpha$ 5\%). The classification of the vaginal maturation index (VMI) 0-49 showed a low estrogen effect, VMI 50-64: moderate estrogen effect, VMI 65-100: high estrogen effect [15] [16].

\section{Finding \& Discussion}

\subsection{Diestrus Lenght}

The average data of diestrus lengths were presented in Fig. 1. The results showed that rats treated with a combination of pegagan and beluntas extract experienced longer diestrus compared with control. The control (C) rats had an average length of diestrus for $47.4 \pm 1.99$ $\mathrm{h}$. T1 had a diestrus length for $51.6 \pm 2.35 \mathrm{~h}$. The diestrus phase in the T2 group experienced an average length for $69 \pm 1.99 \mathrm{~h}$ per cycle. T3, the average diestrus remained for $57 \pm 3.11 \mathrm{~h}$. The longest extension of diestrus phase was seen in T4 (dose $125 \mathrm{mg} / \mathrm{kg} \mathrm{bw}$ ) with average, ie $76.8 \pm 1.93 \mathrm{~h}$, while at $\mathrm{T} 5$, the highest dose of $200 \mathrm{mg} / \mathrm{kg}$ bw decreased the length of diestrus up to $70.8 \pm 3.12 \mathrm{~h}$. 


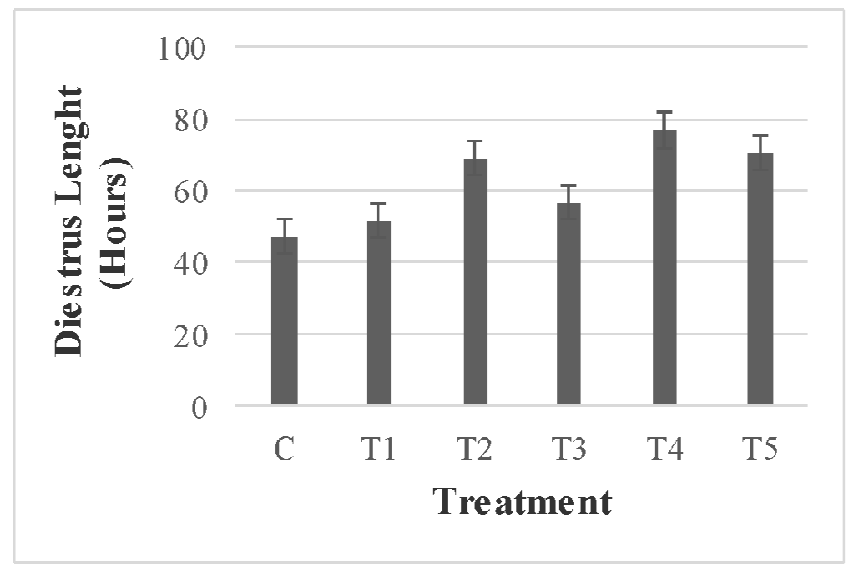

Figure 1. The average of diestrus lenght for 15 days treatment.

Statistical analysis of diestrus length data showed no significant difference between treatments. The length of diestrus phase in normal rat refers to Shanon, et al., (2012) lasts 48$72 \mathrm{~h}$. Thus the range of diestrus phase in each treatment group (47.4-76.8) was still in the normal category [17].

This was influenced by the content of phytoestrogens in the natural ingredients. The high content of phytoestrogens could cause a negative feedback mechanism on the hypothalamuspituitary axis that could extend the diestrus phase and estrous cycle.

\subsection{Proliferation of vaginal ephitelial Vaginal Maturation Index}

Observation of rat vaginal epithelial proliferation included consideration of vaginal maturation index and vaginal epithelial thickness. Vaginal maturation index reflects the level of estrogen effect on cellular maturation.

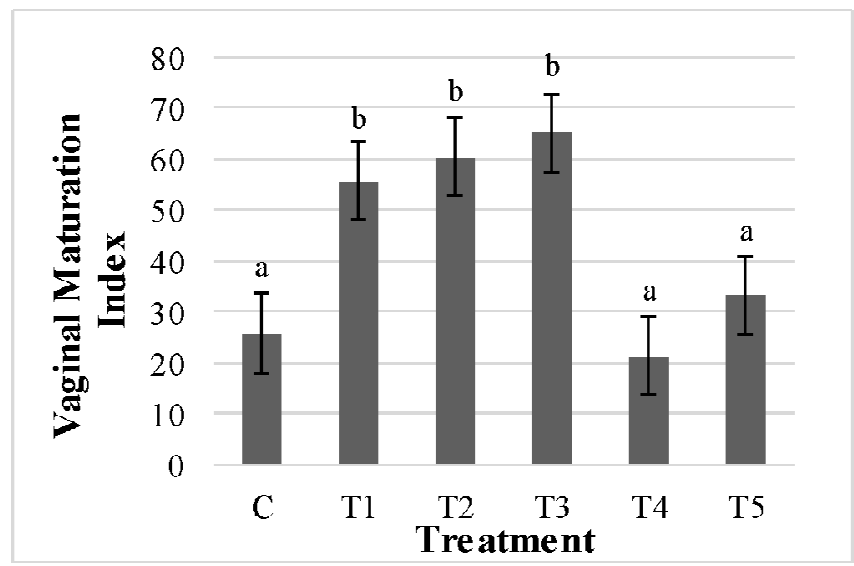

Figure 2. The average of vaginal maturation index after 15 days treatment. 
The analysis of variance result revealed that the combination of pegagan and beluntas extracts affected the vaginal maturation index. The further test used DFMRT ( $\alpha$ 5\%) to determine the effective dose of the treatments. The results were obtained in Fig. 2.

Fig. 2 showed the value of vaginal maturation index of the control group (C) of $25.88 \pm$ 1.65 , indicating low estrogen effect, not significantly different with T4 $(21.31 \pm 3.88)$ and T5 $(33.42 \pm 1.15)$. T3 resulted in the highest maturation index of $65 \pm 1.15$ (high estrogen effect), not significantly different with T2 of $60.34 \pm 2.78$ (medium estrogen effect), and T1 of 55.86 \pm 4.06 (moderate estrogen effect) but substantially different from other treatments.

Table 1. Distribution Of Vaginal Epithelial Cells After 15 D Treatment

\begin{tabular}{|c|c|c|c|}
\hline \multirow{2}{*}{ Treatments } & \multicolumn{3}{|c|}{ Cell average } \\
\cline { 2 - 4 } & Parabasal (\%) & Intermediet (\%) & Superficial (\%) \\
\hline C & 66.31 & 18.02 & 15.67 \\
\hline T1 & 20.39 & 48.87 & 30.74 \\
\hline T2 & 18.10 & 43.49 & 38.41 \\
\hline T3 & 5.69 & 57.97 & 36.33 \\
\hline T4 & 66.68 & 24.44 & 8.88 \\
\hline T5 & 45.63 & 41.91 & 12.46 \\
\hline
\end{tabular}

The high percentage of superficial cells on T1, T2, and T3 indicated that the differentiation of cells in these groups run well. A sharp decrease in superficial cell percentage occurred in T4 and T5. This suggests that the process of differentiating epithelial cells in these groups was slow. This result was proportional to the vaginal maturation index value in $\mathrm{T} 4$ and T5. The high percentage of superficial cells indicated high estrogen effects, whereas high parabasal cells showed a low estrogen effect in the body. Estrogen deficiency would result in decreased epithelial proliferation as well as epithelial maturation into intermediate and superficial cells. This happens because all layers were missing except the basal cell layer [18].

\subsection{Vaginal Epithelium Thickness}

The analysis of variance result indicated that vaginal epithelium thickness had significant differences between control and other treatments. Based on the DMRT ( $\alpha$ 5\%) results, the following notations were presented on Fig. 3. Fig. 3 revealed that the higher the dose was given, the higher the thickness of the vaginal epithelium. The highest vaginal epithelial thickness was found in T5 $(0.63 \pm 0.06)$ followed by T3 $(0.53 \pm 0.05)$, T1 $(0.41 \pm 0.04)$, T4 $(0.37 \pm 0.03), \mathrm{T} 2(0.37 \pm 0.03)$ and control $(0.35 \pm 0.01)$. Vaginal maturation index and vaginal epithelial thickness were obtained from vaginal histology. Histological profile of rat vaginal tissue treated by the combination of pegagan and beluntas extract with HE staining presented in Fig. 4. Fig. 4 showed the thickness of the vaginal epithelium and the superficial, intermediate, parabasal cell composition between treatments. 


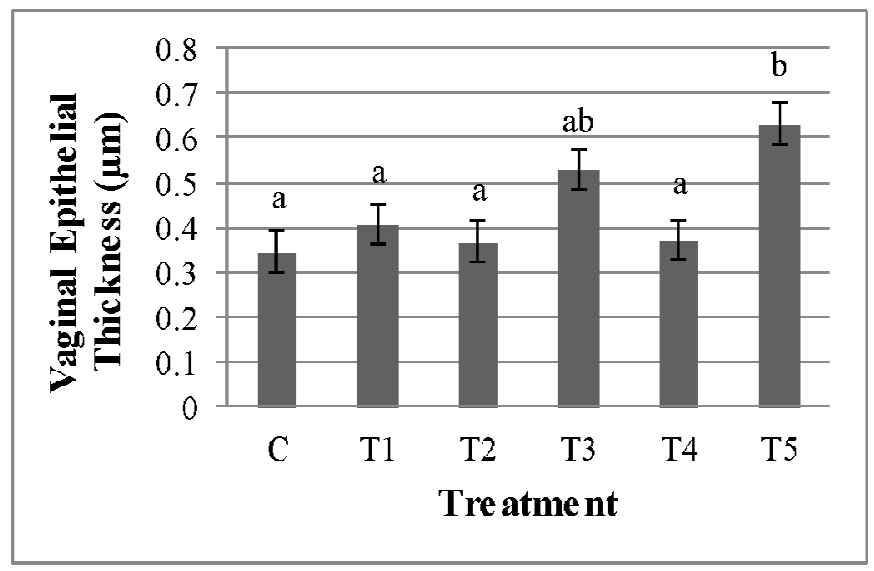

Figure 3. The average of vaginal epithelium thickness after 15 days treatment.

Safrida study (2011) revealed that ovariectomy rat fed by $100 \mathrm{~g}$ dry weight $/ \mathrm{kg} \mathrm{bw} /$ day soybean flour and tempeh flour affect length of the estrus phase, the proliferation of vagina epithelia cell, and estrogen level. Normal rat fed by $100 \mathrm{~g}$ dry weight $/ \mathrm{kg}$ bw/day tempeh flour have a prolonged of diestrus phase and estrus cycle but not in soybean flour [19]. The differentiation of vaginal epithelial cells may influence the thickness of the vaginal epithelial layer. The distinction is a structural and functional change of cells to maturity. Differentiation can occur directly or indirectly through estrogen binding on each estrogen receptor (ER) $\alpha$ in stromal and epithelial cells. The mechanism of epithelial cell differentiation is more complicated, but it is known that epithelial differentiation events require a proliferation process first. Cell differentiation can be seen from the cytological changes in vaginal epithelial cells, i.e., parabasal cells into superficial cells in the vaginal epithelial lining. It then causes keratinization in the upper layers of the vaginal epithelium [20]. 

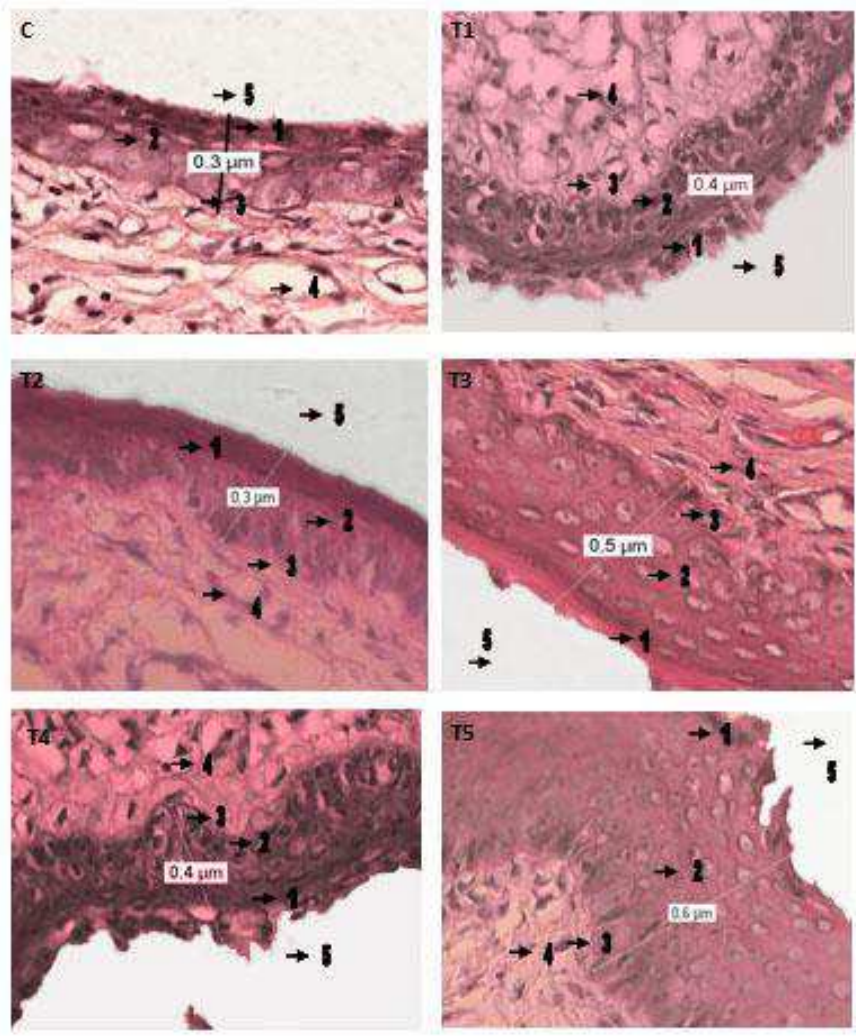

Figure 4. Histological profile of rat vagina after 15 days of treatment. M: 400x. (1.Superficial cell, 2. Intermediate cell, 3. Parabasal cell, 4. Muscular layer, 5. Lumen of vagina).

Castelo-Branco, et al., (2005) revealed that laboratory diagnosis is based on the value of vaginal maturation (VMV), can identify vaginal atrophy caused by a decreased number of a superficial cell [21]. Several hormonal and nonhormonal methods have been proposed to reduce the negative impacts caused by vaginal atrophy [22]. So far, estrogen therapy is the only effective method through which the collagen content of the skin and its thickness are improved [21].

Combination of pegagan and beluntas that contains phytoestrogens can increase the band thickness of the ER $\alpha$ protein [20]. The expression of ER $\alpha$ is much higher than the ER $\beta$ in the vagina. The Er $\alpha$ is required for the proliferation, stratification and keratinization of vaginal epithelial cells induced by estrogen. ER $\beta$ alone is not sufficient to mediate the estrogen effect in the absence of ER $\alpha$ [23]. Because of the existence of ER $\alpha$, vaginal epithelial cells can proliferate in response to phytoestrogens [23] from these plants.

The effect of estrogen will be obtained optimally if using the right dose. The results showed that in the vagina, a dose of $75 \mathrm{mg} / \mathrm{kg}$ bw could give the highest effect. This was consistent with the results of the Muchtaromah (2017) study [6] which proved that the highest estrogen levels in the blood were obtained in combination of pegagan and beluntas extracts at doses of $75 \mathrm{mg} / \mathrm{kg}$ bw. At higher doses (T4) and (T5) actually had the opposite effect because of the negative feedback mechanism from the hypothalamic-pituitary-gonad axis. Raden (2011) reported that extract of Pegagan at ovariectomized rat at doses of $30 \mathrm{mg}, 60 \mathrm{mg}$, and 
$120 \mathrm{mg} / \mathrm{kg}$ bw respectively as long as $40 \mathrm{~d}$, increased the thickness and elasticity of vaginal wall [14].

Beluntas has active compounds such as flavonoids, alkaloids, triterpenes, tannins [24], monoterpenes or sesquiterpenes, sterols, phenols, and hydroquinones [25]. Pegagan has the main active ingredient, terpenoid, especially triterpenoid, consisting of asiaticoside, centellosida, madecassoside, brahmosida and brahminosida (saponin glycosides), asiaticentoic acid, centellic acid, centoic acid and madecassic acid [26]. Triterpenoid saponins contain steroids called diosgenin or often called genins. Genin is used as a raw material for the synthesis of steroid hormones. It can be converted into progesterone through a series of chemical processes that produce testosterone and estradiol [5].

Saponins, alkaloids and triterpenoids allegedly entered the steroid biosynthesis pathway, especially estrogen that will produce material which has a structure similar to estrogen (phytoestrogen). Furthermore, phytoestrogens and estrogens are secreted to target cells together. They will compete in binding to estrogen receptors, consequently, the action of estrogen on target cells will decrease [27]. Pebdani, et al. (2014) reported that participants received Ginkgo biloba extract containing phytoestrogens at doses of 120-240 mg daily for 30 $\mathrm{d}$ had a positive effect on the sexual desire of menopausal women [28].

\section{Conclusion}

The combination of leaf extract of pegagan and beluntas significantly influenced the proliferation of vaginal epithelium, indicated by the increase of maturation index and vaginal epithelial thickness, but did not affect to the length of diestrus. The highest vaginal maturation index and vaginal epithelial thickness value obtained by T4 dose of $75 \mathrm{mg} / \mathrm{kg}$ bw, thus this dose was the most optimal for use as a fertility supplement.

Acknowledgements. We expressed our gratitude to Mr. Mujahidin Ahmad, Ihda Sayidatun Nasiroh, Hestry Amita, Wahyuningrum, and Mukholifah as a solid research team for their cooperation and to Mr. Asis Wahyudi for the article proofreading. This paper in conjunction with The 1st International Conference on Islam, Science and Technology (ICONIST 2018) in Malang, East Java, Indonesia.

\section{References}

[1] J.M. Goldman, A. S. Murr, and R. L Cooper, The rodent estrous cycle: Characterization of vaginal cytology and its utility in toxicological studies, Birth Defects Res (Part B), vol. 80, no.2, pp. 84-97, 2007.

[2] Figa-Talamanca, Occupational risk factors and reproductive health of women, Occup Med (Lond), vol. 56, no. 8, pp. 521-531, 2006.

[3] R.S. Shaival,. K.R. Shaival, Review on Centella asiatica: a wonder drug, International Journal of Pharmaceutical and Chemical Sciences, vol. 1, no.3, pp. 1369-1375, 2012.

[4] V. Seevaratnam, P. Banumathi, M.R. Premalatha, S.P. Sundaram, T. Arumugam, Functional properties of Centella asiatica (1.): a review. International Journal of Pharmacy and Pharmaceutical Sciences, vol. 4, no.5, pp. 8-14, 2012. 
[5] Y. Andria, Pengaruh Pemberian Ekstrak Daun Pegagan (Centella asiatica (L) Urban) terhadap Kadar Hormon Estradiol dan Kadar Hormon Progesteron Tikus Putih (Rattus norvegicus) Betina. Skripsi. Malang: UIN Maulana Malik Ibrahim Malang. 2012.

[6] B. Muchtaromah, Mukholifah, S. N. Ihda, A. Mujahidin, and Romaidi, Antifertility Effect of Centella asiatica (L) Urban and Plucea indica (L) Urban on The Number of Follicles, Antioxidant Activity and Hormonal Profile of White Rat's Ovaries. Advances in Health Sciences Research (AHSR). vol. 5, pp. 235-240, 2017.

[7] Yuliani and Y. S. Rahayu, The Using of Fenolic Compounds of Pluchea indica (L.) Less. Leaves Extracts as a Bioinsecticide and Bioherbicide, J. Phys.: Conf. Ser, vol. 953, no. 1, 2018.

[8] Ahmed, A. Sayed, Kamel, M. Emadeldin, Phenolic Constituents and Biological Activity of the Genus Pluchea. Scholars Research Library Der Pharma Chemica, vol. 5, no. 5, pp. 109-114, 2013.

[9] Sa'roni dan Y. A. Nugroho, Ramuan Obat Tradisional Di Sumatera Barat dan Nusa Tenggara Barat untuk Keluhan Pada Sistem Reproduksi, Artikel Media Litbang Kesehatan, vol.22, no.3, 2012.

[10] I. Fajriaty, Pengaruh Rebusan Daun Beluntas (Pluchea indica. L. Less) terhadap Siklus Estrus dan Jumlah Kelahiran Janin pada Tikus Betina Galur Wistar : Skripsi. Universitas Islam Indonesia. 2008 .

[11] B. Muchtaromah, Pengaruh Ekstrak Pegagan (Centella asiatica (L) Urban) Dosis Tinggi terhadap Profil Folikel Ovarium Mencit (Mus musculus) Betina, Berkala Penelitian Hayati (Journal of Biological Researches), Edisi Khusus no. 4D, Juni 2011.

[12] B. Muchtaromah, M. Ahmad, Suyono, Romaidi, S. Bahri, H. P. Kumalasari, Dosage and Administration Length of Centella asiatica (L.) Urban Decrease the Level of SOD and MDA and Improve Brain Histological Condition of Rats, Jurnal Teknologi, vol. 78, no. 5, pp. 57-61, 2016.

[13] M. C. Cora, L. Kooistra and G. Travlos, Vaginal Cytology of the Laboratory Rat and Mouse: Review and Criteria for the Staging of the Estrous Cycle Using Stained Vaginal Smears. Toxicologic Pathology, vol. 43, no.6, pp. 776-793, 2015. DOI: 10.1177/0192623315570339.

[14] R. Abkar. Efek Ekstrak Pegagan (Centellaasiatica) pada Rattus norvegicus Wistar yang Dilakukan Ovariektomi Terhadap Proliferasi Epitel pada Dinding Vagina, Jurnal Ilmiah Kedokteran Hewan, vol. 4, no. 1, Februari 2011.

[15] A. I. Immanuel, J. Wantania, E. Suparman and P. Lintong, Clinical Appearance and Vaginal Cytology of Atrophic Vaginitis in Postmenopausal Women. Indones Journal Obstet Gynecol. Vol. 34, no. 2, pp. 92-96, 2010.

[16] W. M. M. Nelly, R. Handarini, M.R. Raden, I. Arifiantini , T. Laswardi, Y.B. Purwantara, Penentuan Siklus Estrus Berdasarkan Gambaran Sitologi Vagina dan Profil Hormon pada Rusa Timor. Jurnal Veteriner, vol. 12, no. 2, pp. 98-106, 2011. ISSN : 1411 - 8327

[17] S.L. Byers, M. V. Wiles, S. L. Dunn, and R.A.Taft, Mouse Estrous Cycle Idntification Tool and Images. PLoS One, vol. 7, no. 4, 2012. Doi: 10.1371/journal.pone.0035538.

[18] R Amran, Menentukan Menopause Berdasarkan Indeks Maturasi dan pH Vagina, Jurnal Kedokteran dan Kesehatan. vol. 42, no.3, 2010.

[19] Sfrida. Perubahan Kadar Hormon Estrogen pada Tikus yang diberi Tepung edelai dan Tepung Tempe : Thesis. Sekolah Pascasarjana. Institut Pertanian Bogor. Bogor. 2011.

[20] D Kusmana, R. Lestari, Setiorini, A.N. Dewi, P.R. Ratri, dan R.R.R. Soraya, fek Estrogenik Ekstrak Etanol 70\% Kunyit (Curcuma domestica val.) Terhadap Mencit (Mus musculus 1.) Betina yang Diovariektomi, Makara, Sains, vol. 11, no. 2, pp. 90-97, 2007.

[21] CCastelo-Branco, M.J.Cancelo, G.Villero, F. Nohales, M. Juli, Managemnt of Post-menopausal Vaginal Atrophy and Atrophic Vaginitis. Maturitas, vol. 52, Suppl. 1, pp. 46-52, 2005.

[22] M. Tadayon, P. Rad, M.R. Abbaspour, S.M. Latifi, I. Rashidi, M. Barati, H. Delaaviz, The Effect of Vitamin D Suppository on Atrophic Vaginal Mucosa in Menopausal Women, Armaghane-danesh Bimonthly Journal, vol.17, no.3, pp.187-195, 2012.

[23] Buchanan, Kurita, Taylor, Lubahn, Cunha, and Cooke, Role of Stromal and Epitel Estrogen Receptor in Vaginal Epithelial Proliferation, Stratification, and Cornification, Journal Endocrinology, vol. 139, no. 10, 1998. 
[24] E.Susetyarini, Khasiat Beluntas Sebagai Antifertilitas (Uji pre-klinis). Malang: UMM Press. 2011

[1] P.S. Widyawati, C.H. Wijaya, Hardjosworo, P.Suprapti dan D.Sajuthi, Evaluasi Aktivitas Antioksidatif Ekstrak Daun Beluntas (Pluchea indica) berdasarkan Perbedaan Ruas Daun. Bogor: IPB. 2012. ejournal.upnjatim.ac.id/index.php/rekapangan/article

[2] J.Barnes, L.A. Anderson, J.D. Phillipson. Herbal Medicines, Second Edition, London: Pharmaceutical Press, 2002.

[3] A. Nurliani, Penelusuran Potensi Antifertilitas Kulit Kayu Durian (Dueio zibethinus Murr) Melalui Skrinning Fitokimia. Sains dan terapan Kimia. vol. 1, no. 2, hal. 53-58, 2007.

[4] M. A. Pebdani, S. Taavoni, N. Seyedfatemi, and H. Haghani, Tripleblind, placebo-controlled trial of Ginkgo biloba extract on sexual desire in postmenopausal women in Tehran, Iranian Journal of Nursing and Midwifery Research. Vol. 19, no. 3, pp. 262265,2014 